\title{
REVIEW
}

\section{Unusual marine ecosystem in the flooded crater of Ushisher volcano}

\author{
A. V. Zhirmunsky, V. G. Tarasov \\ Intistute oi Marine Biology, Far Eastern Branch, Academy of Sciences of the USSR, Vladivostok 690032, USSR
}

\begin{abstract}
This paper reviews investigations of a manine ecosystem in Kraternaya Bight (Yankich Island, Kurile Islands) which has arisen and is functioning under the influence of gaso-hydrothermal vents of the Ushishir volcano. The concentrations of reduced sulphur compounds and a number of metals in the vents are 2 to 3 orders of magnitude higher than in seawater around the island. Together with photosynthesis of algae, chemosynthetic bacteria play an essential part in primary production. Extreme chemical conditions in the outlets of vents have left a mark on the composition of communities and in peculiarities of certain species. Concentrations of some metals are so high that ecosystems of Kraternaya Bight can be considered as a model of sea territory with a high degree of industrial pollution. At the request of the Institute of Marine Biology, Kraternaya Bight has been created a preserve.
\end{abstract}

\section{INTRODUCTION}

Volcanic activity may have been a crucial factor in the origin of life on Earth. Recent investigations have shown that volcanic activity now plays a significant role not only in formation of minerals and rocks but also in production of organic matter.

In 1977, US oceanographers investigated spreading zones on the Pacific Ocean floor around the Galápagos Islands and found, at a depth of $2.5 \mathrm{~km}$, hydrothermal vents with abundant invertebrate animals clustered around them. Two years later, biologists surveyed this area from the submersible 'Alvin'. French researchers later joined the investigation (Laubier \& Desbruyères 1985) and were followed recently by oceanologists from Moscow (Kuznetsov et al. 1989).

A number of new groups of animals were encountered in the hydrothermal fields and the finding of this new kind of ecosystem is justly believed by some to be the great discovery of the century in marine biology (Williams 1985). There are numerous publications devoted to these organisms, but we merely point out that these accumulations of animals are supported by bacterial chemosynthesis, where bacteria produce organic substances from carbon dioxide using reduced compounds from the heated effluents as a source of energy (Corliss et al. 1979, Grassle et al. 1979, Lutz \& Hessler 1980, Turner 1981).
From the results of these studies, from data on land volcanic discharge (see for example Zavarzin et al. 1967), and taking into account the similarity of the chemical composition of deep-sea hydrothermal waters and waters of land volcanic discharges, we suggested that specific communities of marine organisms may exist in shallow coastal areas subjected to active volcanism, such as near the Kurile Islands. Despite scepticism from colleagues a small expedition was sent to the Kurile Islands aboard the hydrographic vessel 'Taimyr' in August 1985. Investigations were continued in 1986 and 1987. This paper is a review of these investigations, the results of which were published in Russian (with English summaries) in 'Biologiya Morya' (Vladivostok), No 3, 1989. These papers present a quite detailed description of the microbiology, hydrobiology and hydrochemistry of the system. Here we confine ourselves to a brief review of these papers, information on the expeditions to Kraternaya Bight, and description of methods and areas of sampling.

\section{SAMPLING AREAS AND METHODS}

In 1985, the scientific team consisted of 4 hydrobiologists and hydrochemists.

Based on results of earlier studies conducted by the Institute of Volcanology, and on hydrobiological evi- 


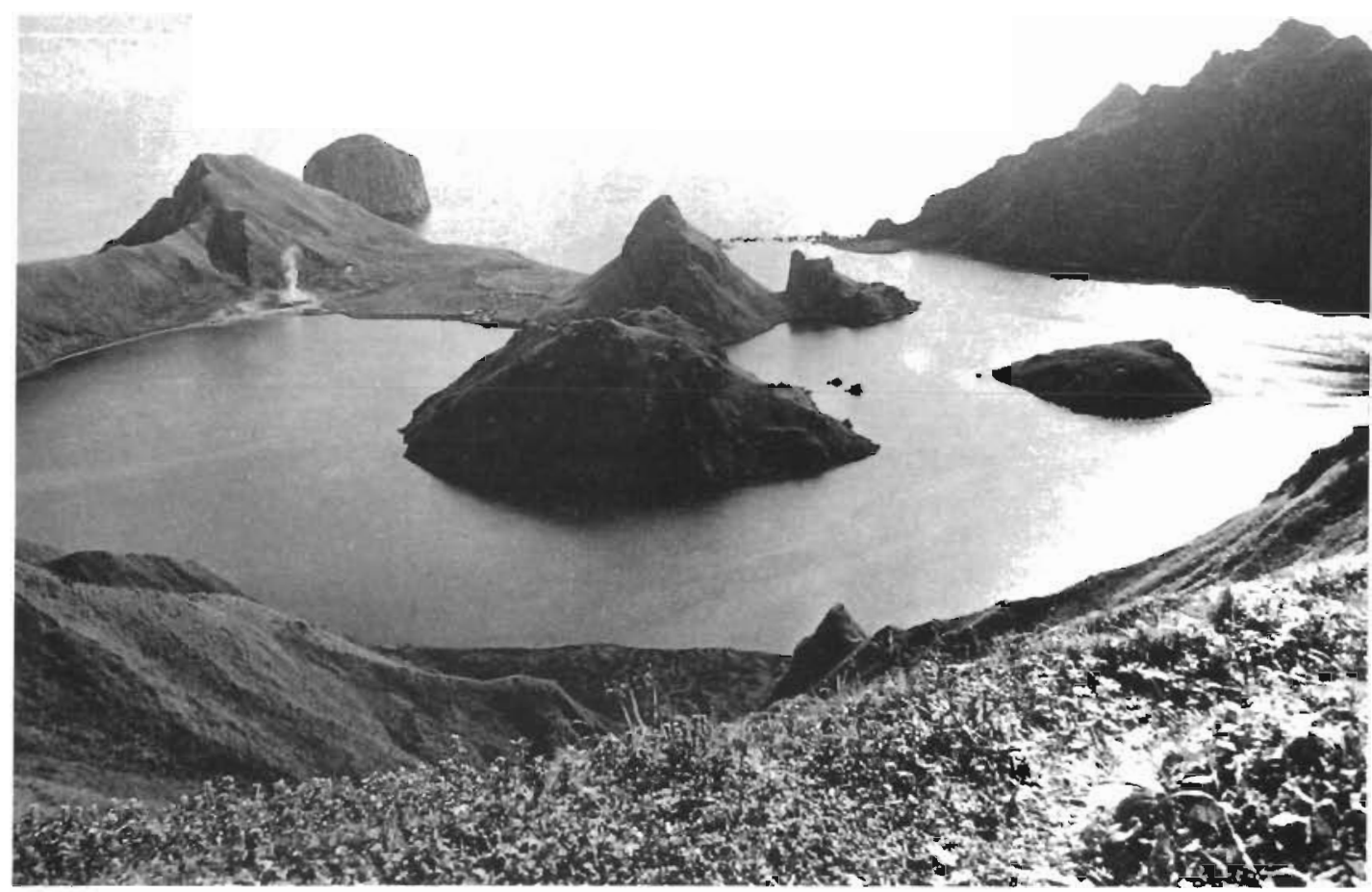

Fig. 1. View of Kraternaya Bight from the circular ridge

dence, Kraternaya Bight on Yankich Island in the Mid Kurile Islands was selected for study. The bight is a crater of the Ushishir volcano, flooded by the sea several thousand years ago (Gavrilenko et al. 1989). A narrow and shallow channel connects the bight with the Pacific Ocean. The water surface of the bight is about $0.7 \mathrm{~km}^{2}$ and the maximum depth is about $63 \mathrm{~m}$. There are 2 islets - extrusion rocks - in the centre of the bight. The bight is surrounded by a circular mountain ridge, with a highest peak of $400 \mathrm{~m}$ (Fig. 1). Some results of the 1985, 1986 and 1987 expeditions have been reported (Tarasov et al. 1986, 1989).

From August 22 to September 2, 1986, an expedition to Kraternaya Bight was organized aboard 2 research vessels, Academician Oparin' and 'Beril'. Seventeen persons participated in it: 10 hydrobiologists, 3 microbiologists, 2 hydrochemists, 1 geochemist and 1 driver.

In the same year, a group of scientists from the Institute of Volcanology (Far Eastern Branch, USSR Academy of Sciences) worked in the bight. Their task was to study processes of modem ore formation in zones of hydrotherms, to determine the heat balance and heat power of Ushishir volcano (Gavrilenko et al. 1989).

In 1987, researchers worked in a temporary camp on Yankich Island for 3 mo. This expedition used the hydrometeorological vessel 'Priboy' from the Far East Hydrometeorological Institute.

SCUBA surveys of the bight bottom to the depth of $45 \mathrm{~m}$ were made. Searches for zones of gaso-hydrother- mal activity were made by visually locating the emission of gas bubbles from the bottom, by water temperature measurements, and by sampling gas, bottom sediments and microbiological materials (algobacterial and bacterial mats), as well as by recording the density of settlements and biomass of macrobenthos.

Main hydrochemical measurements were made at 2 permanent stations (Fig. 2). At different times, water samples for analysis were also collected from volcanic flows on the bight coast, from the intertidal zone, from various bight areas directly over the underwater gasohydrothermal vents, and from the bight strait and outside Yankich Island. In 1986, at Stn 1, samples were collected for 24 h at 3 to $4 \mathrm{~h}$ intervals. In 1987, sampling was repeated for $30 \mathrm{~h}$ at $2 \mathrm{~h}$ intervals at the same station, as well as at both Stns 1 and 2 twice a day (in the morning and evening) in August, September and October. All samples were accompanied by water temperature measurements. Water for analyses was taken at each station with a submersible electric pump and plastic hose from depths of $0,1,2,4,5,8$ and $10 \mathrm{~m}$ and thereafter at every $5 \mathrm{~m}$ to the bottom.

Salinity, total alkalinity, carbonate, $\mathrm{pH}$, oxygen content, and contents of dissolved orthophosphate, ammonia, nitrite, nitrate, silicon, hydrogen sulphide, other reduced sulphur compounds, and chlorophyll a in water samples were determined by standard methods (Strickland \& Parsons 1972). Water analyses were made immediately after sampling on board the vessel or at the laboratory on the bight coast (Propp et al. 1989) 


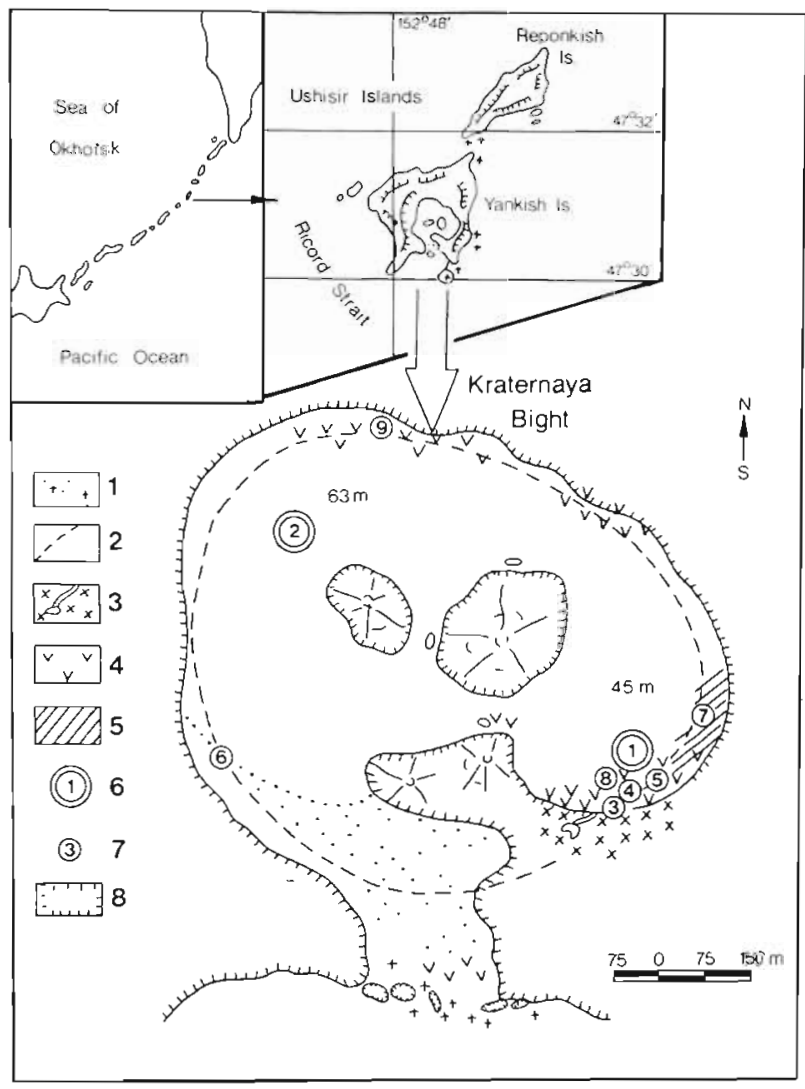

Fig. 2. Schematic map of Kraternaya Bight with positions of gaso-hydrothermal vents. 1, Sandbank and stones in the bight strait; 2 circular break in the bight floor; 3 , terrestrial hydrosolfatara field, boiling volcanic spring and a brook; 4 , areas of intertidal and underwater gaso-hydrothermal vents; 5 , an area of volcanic seep; 6 , permanent hydrochemical stations; 7 , sampling stations for microbiological analysis and measurements of metabolism of bottom communities; 8 , crater slopes

Dissolved (0.2 um pore size) metals ( $\mathrm{Mn}, \mathrm{Zn}, \mathrm{Cu})$ were determined by atom-absorption after concentration by diethyldithiocarbaminate in chloroform. Metal contents in particulate matter were determined after their decomposition in $\mathrm{HF}$ and $\mathrm{HNO}_{3}$ by the same method. Samples of depositing sediment were collected in traps situated near Stns 1 (1.5 $\mathrm{m}$ depth) and 2 (30 m depth) (Shulkin 1989).

To determine the composition of plankton, water samples were taken from permanent stations, from different areas and depths of the bight, and from the outside of Yankich Island using a plastic bathometer, Jedey plankton net (50 $\mu \mathrm{m}$ pore size) and a submersible pump. Organisms were identified to species, and the density and biomass of populations were determined.

In order to measure rates of oxygen consumption (ROC) and production (ROP) in communities inhabiting stony ( $\operatorname{Stn} 5,5 \mathrm{~m}$ ) and sandy bottoms ( $\operatorname{Stn} 6,4$ to $5 \mathrm{~m}$ ), algobacterial mats ( $\operatorname{Stn} 7,6 \mathrm{~m}$ ), and muddy sediments with and without bacterial mats (Stn 8, $22 \mathrm{~m}$ ), we sampled small stones overgrown with diatomy mats and undisturbed columns of bottom sediments and mats; these were placed into glass respirometers and tubes (38 mm diameter). Mat samples were collected in hydrothermal vents and in zones of volcanic water seepage. Only samples with no benthic animals larger than $2 \mathrm{~mm}$ were used. Six experiments were conducted.

ROC and ROP were measured in a flow-through experimental system, placed in a flow-through tank on the bight shore for thermostating (Tarasov et al. 1989).

ROC and ROP for stones, sediments and mats were calculated using equations for unstable processes in flow-through respirometers (Propp et al. 1982).

Microbiological investigations were carried out at Stns 3 and 4. Various types of microorganisms were enumerated in various enrichment media. The intensity of microbiological processes - production (growth), sulfate reduction, methane oxidation, methane formation, cellulose decomposition in mats and bottom sediments - was determined in experiments with appropriate radionuclides $\left(\mathrm{H}^{14} \mathrm{CO}_{3}, \quad \mathrm{Na}_{2}{ }^{35} \mathrm{SO}_{4},{ }^{14} \mathrm{CH}_{4}\right.$, ${ }^{14} \mathrm{CH}_{3} \mathrm{COO}^{-}$and ${ }^{14} \mathrm{C}$-cellulose) (Borzenkov et al. 1989, Karnachuk et al. 1989, Namsaraev et al. 1989, Starynin et al. 1989).

\section{RESULTS}

Earlier studies had described hot solfatara effluents with water temperatures of about $100^{\circ} \mathrm{C}$ and a warm spring which flowed into the bight from the southeast. The 1985 expedition found many underwater springs in the intertidal zone and down to $30 \mathrm{~m}$ depth; they were mostly of 2 types: one containing sulphur compounds and another with ferrous oxides. Temperatures of surface waters in the bight were 9 to $12^{\circ} \mathrm{C}$, compared to only 2.5 to $3.5^{\circ} \mathrm{C}$ around the outside of the Island. Underwater vents with temperatures of $30^{\circ} \mathrm{C}$ were grouped in the southeast, north and south of the bight in a circular break in the base of the volcano (Fig. 2).

The land solfatara and underwater vents produce more than $20000 \mathrm{~m}^{3}$ of hydrothermal water per day. These hydrothermal waters contain high concentrations of manganese (up to $6000 \mu \mathrm{g} \mathrm{l}^{-1}$ ), iron (up to $\left.350 \mu \mathrm{g} \mathrm{l}^{-1}\right)$, zinc $\left(23 \mu \mathrm{g} \mathrm{I}^{-1}\right)$, copper $\left(25 \mu \mathrm{g} \mathrm{l}^{-1}\right)$, nickel $\left(13 \mu \mathrm{g} \mathrm{l}^{-1}\right)$, cadmium $\left(2.2 \mu \mathrm{g} \mathrm{l}^{-1}\right)$ - values 2 to 3 orders of magnitude more than in waters surrounding the bight (0.18 to $2.09 \mu \mathrm{g} \mathrm{I}^{-1}$; Shulkin 1989) - hydrogen sulfide (up to $340 \mu \mathrm{g}$-at. $\mathrm{S}^{-1}$ ), other sulfur compounds, silicon and phosphorus.

Seawater inflow into the intermediate layer occurs at irregular tides. The difference between levels at high 
and low tides is up to $1 \mathrm{~m}$; on average about $700000 \mathrm{~m}^{3}$ of seawater flows into the bight. The same volume of water, now warmed $\left(9\right.$ to $\left.12^{\circ} \mathrm{C}\right)$, of slightly lowered salinity ( 31 to $32 \%$ ), and rich in particulate matter and metal contents, flows out of the bight at low tide. Gavrilenko et al. (1989) calculated a thermal balance of the bight and showed that about $20000 \mathrm{~m}^{3}$ of hydrothermal waters are brought daily into the bight through bottom sediments.

It was shown that the contents of oxygen and biogenic (nutrient) elements $\left(\mathrm{N}-\mathrm{NH}_{4}, \mathrm{~N}-\mathrm{NO}_{2}, \mathrm{~N}-\mathrm{NO}_{3}\right.$, $\mathrm{P}-\mathrm{PO}_{4}, \mathrm{SiO}_{2}$ ) differ significantly in different parts and at different depths within the bight. The maximum oxygen concentration was found in surface waters around underwater hydrothermal fields; it was double that in the open sea $\left(14.5 \mathrm{ml} \mathrm{O}_{2} 1^{-1}\right.$ or $200 \%$ saturation). Oxygen content fell with depth as concentration of biogenic substances increased. Gas samples taken from vent hydrotherms contained carbon dioxide (44 to $66 \%$ ); $\mathrm{N}_{2}$ (27 to $42 \%$ ); helium, methane $(0.01$ to $0.03 \%$ ); and hydrogen (0.05 to $0.2 \%$ ).

Bight waters were stratified in terms of temperature, acidity, oxygen content (Fig. 3) and chemical composition (Fig. 4). Upper water layers, with temperatures of 9 to $12^{\circ} \mathrm{C}$, had high volcanogenj.c carbon dioxide contents (up to $2000 \times 10^{-6}$ torr) (Tarasov et al. 1989). Hydrogen sulfide ( 5 to $40 \mathrm{ug}$-at. $\mathrm{I}^{-1}$ ) and ammonia (up to $26.0 \mu \mathrm{M}$ ) were found in the 0 to $20 \mathrm{~m}$ water layer over hydrothermal vents, particularly in the southeastern part of the bight.

The most intensive photosynthesis was observed in the upper 1 to $2 \mathrm{~m}$ water layer. Below 5 to $10 \mathrm{~m}$, respiration predominated over production (Tarasov et al. 1989)

In the afternoon, 'red tides' were often observed in the bight. It was found that these were caused by vertical migrations of the infusorian Mesodinium rubrum harbouring a symbiotic microalgae, Chroomonas.

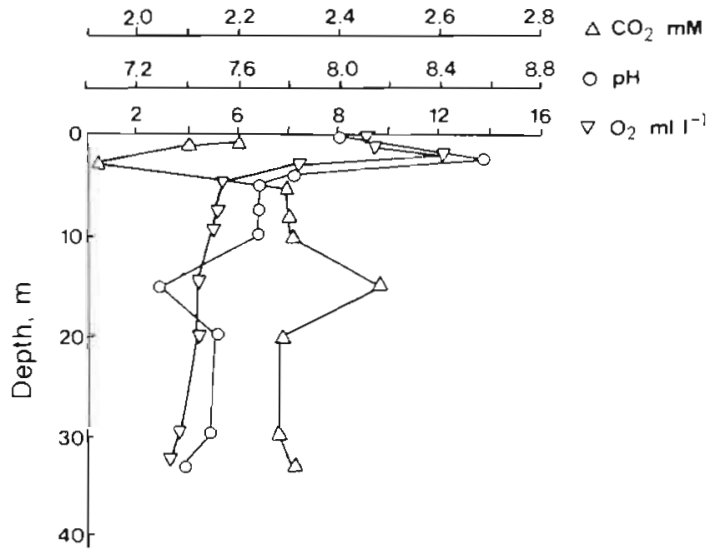

Fig. 3. $\mathrm{O}_{2}, \mathrm{pH}$ and total carbonate content of bight waters at different depths. Stn 1, September 1987, 18:00 to 19:00 h (Tarasov et al. 1989)

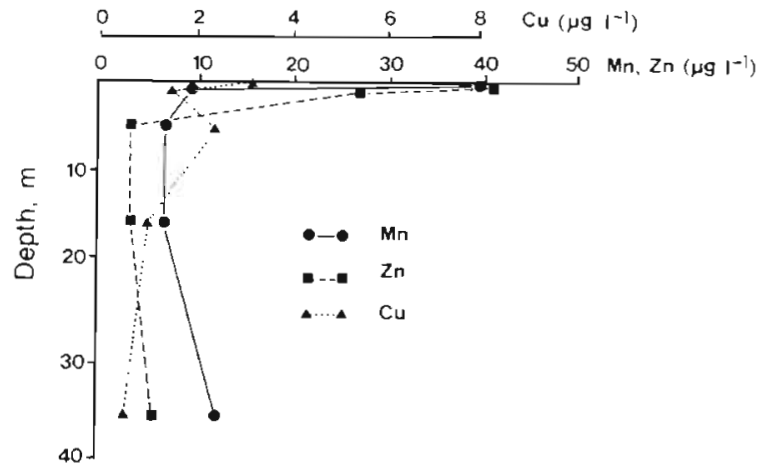

Fig. 4. Dissolved manganese, zinc and copper contents of bight waters (Shulkin 1989; Stn 1)

During the night $M$. rubrum accumulated at depths of 8 to $10 \mathrm{~m}$ and rose to the water surface in the afernoon.

The biomass of plankton was high not only in the upper water layer but especially at 20 to $40 \mathrm{~m}$ (up to $1 \mathrm{~g}$ $\mathrm{m}^{3.3}$ ). Some groups of planktonic organisms, for example larval bivalves, solitary coral larvae and Sagitta sp. (Chaetognatha), were abundant in the bight but were not found around the outside of the island.

Waters of the bight contained much particulate and dissolved organic matter. The average content of dissolved matter was 5 to 8 times higher in the bight than outside the island (5 to $8 \mathrm{mg} \mathrm{Cl}^{-1}$ and $1 \mathrm{mg} \mathrm{C} \mathrm{I}^{-1}$, respectively) (Khristoforova 1989).

Around the hydrothermal vents, from the intertidal zone down to $30 \mathrm{~m}$ depth, algobacterial or bacterial mats are formed, representing aggregations of bacteria of various physiological types, and various species of diatoms (Tarasov et al. 1989). Different bacterial types occur in different vertical layers of the mats and form structures of from 2 or 3 up to $20 \mathrm{~cm}$ thickness (Fig. 5).

Production of algobacterial mats at 1 to $5 \mathrm{~m}$ depth in Kraternaya Bight, according to Starynin et al. (1989), reached 12.8 to $33.4 \mathrm{~g} \mathrm{C} \mathrm{m}^{-2} \mathrm{~d}^{-1}$ of organic carbon. Microbiological studies showed that in these mats chemosynthetic production was considerably higher than photosynthetic production (diatoms and photosynthetic bacteria) (Starynin et al. 1989).

A. rich and diverse macrobenthos flourished on the bottom of the bight (over 200 species have been already identified). Macrophytes were represented in the intertidal and in some parts of upper subtidal zones by algae of the genera Fucus, Laminaria, Ulvaria, Punctaria, Cystoseira, Alaria and others. Some Alaria specimens around the outside of the island were longer than $25 \mathrm{~m}$ (this is the largest algal species in the seas of the USSR), while in the bight this alga did not exceed $8 \mathrm{~m}$. It achieved a biomass of up to $30 \mathrm{~kg}$ wet $\mathrm{wt} \mathrm{m}^{-2}$ in the north part of the bight (depth 5 to $8 \mathrm{~m}$ ), in the vicinity of cold effluents free of hydrogen sulfide but high in $\mathrm{N}-\mathrm{NH}_{4}, \mathrm{P}_{-} \mathrm{PO}_{4}$, iron and manganese. 


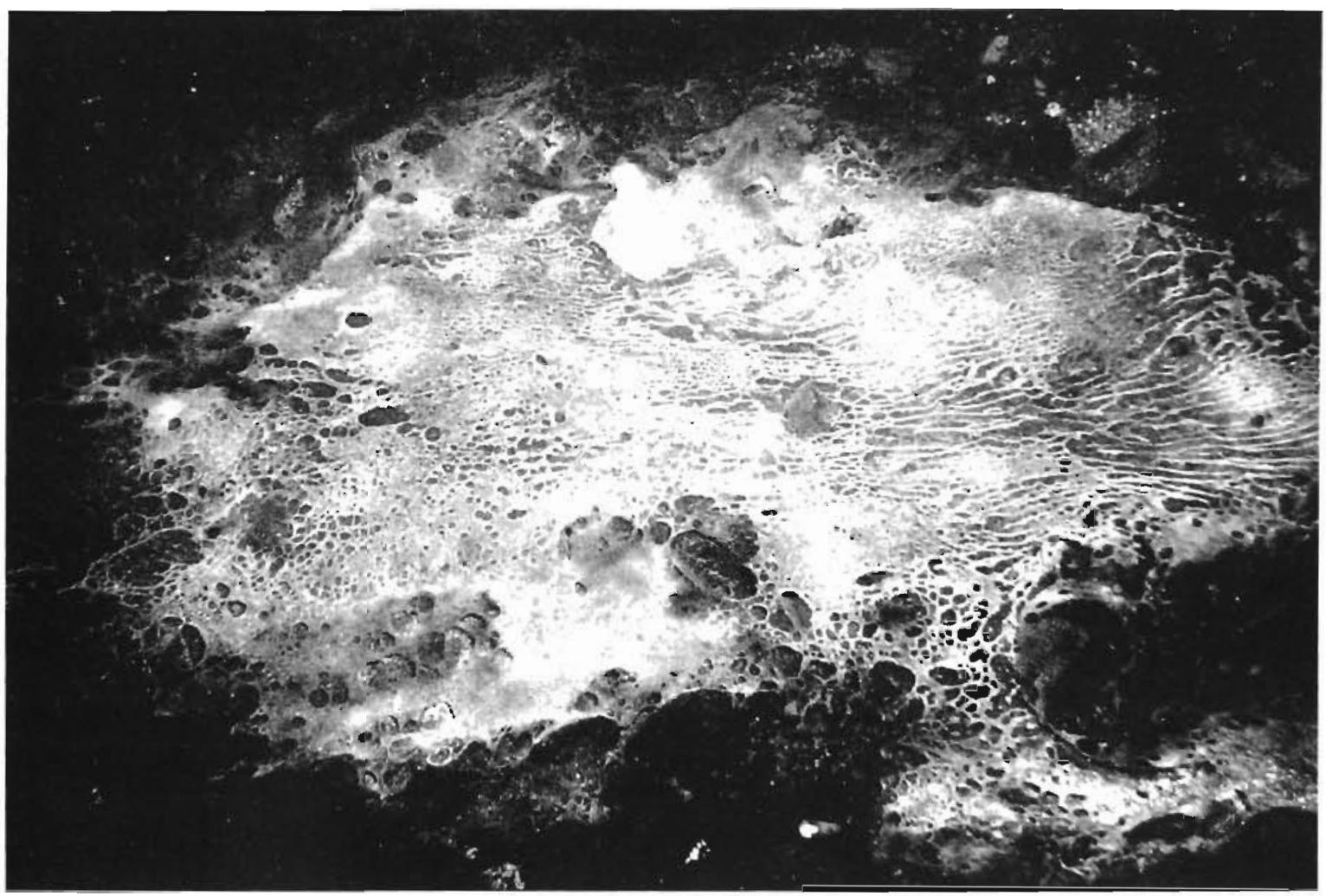

Fig. 5. Algobacterial mats develop in areas of volcanic seep. Depth $5 \mathrm{~m}$

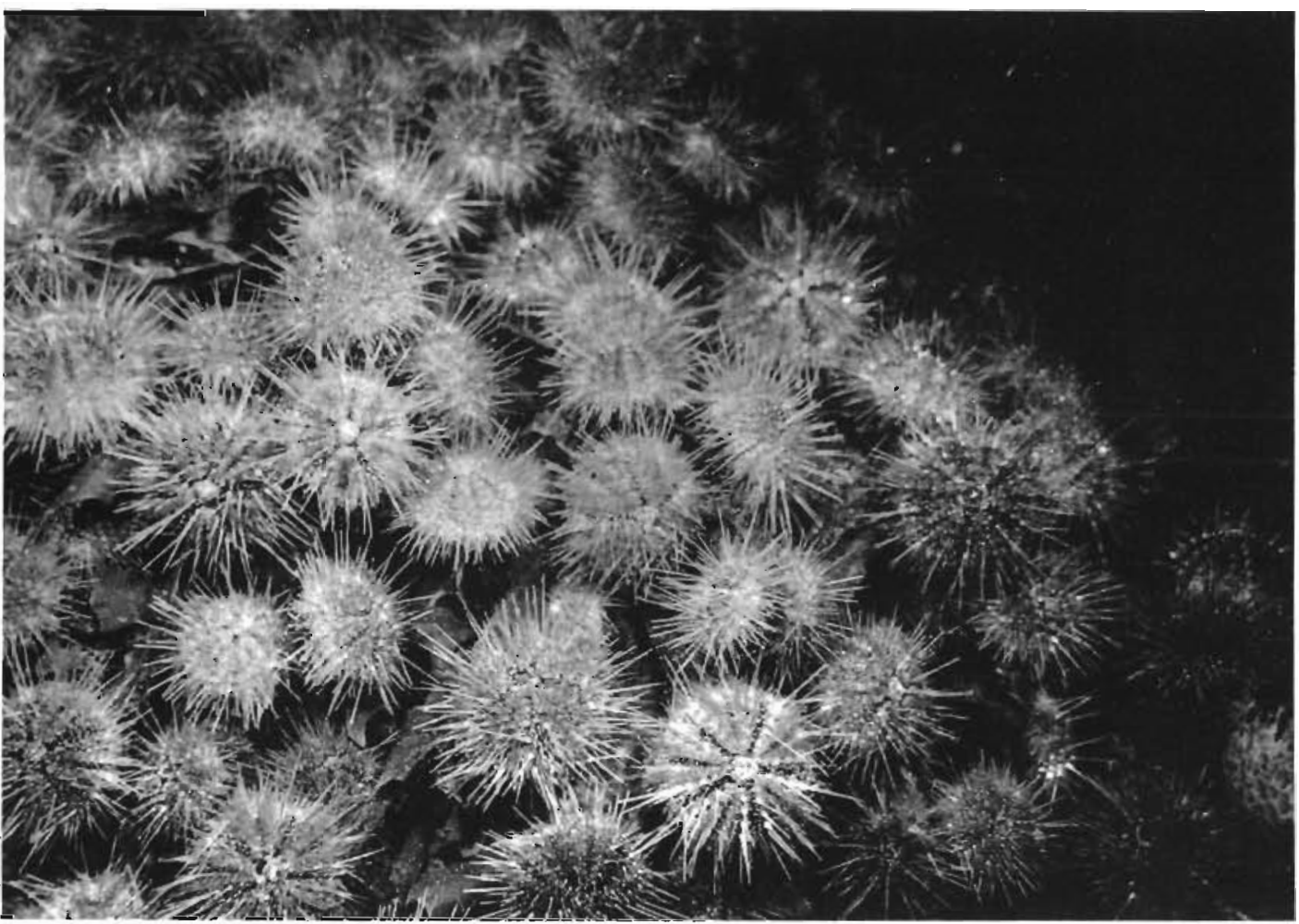

Fig. 6. Aggregations of sea urchins at a depth of 2 to $5 \mathrm{~m}$ 
The vertical distribution of invertebrates in the bight showed a distinct zonation. In the intertidal zone, stones were covered with numerous barnacles (Balanus crenatus, Semibalanus cariosus and others) and gastropod mulluscs such as Littorina kurila. At a depth of 2 to $5 \mathrm{~m}$, the sea urchin Strongylocentrotus droebachiensis predominated (Fig. 6). The sea urchins were one third the size of those from the open shore but formed dense aggregations of up to 1500 ind. $\mathrm{m}^{-2}$; these sea urchins lay in several layers. It seems that they have a short life cycle, which is sometimes the case with animals exposed to extreme conditions. The polychaete Myxicola influndibulum was also smaller inside the bight than outside.

Somewhat deeper, holothurians (sea cucumbers) predominated. Among these, a new species of the genus Psolus (Fig. 7) and one species new to the seas of the USSR, Eupentacta pseudoquinquesemita were found at a depth of 10 to $15 \mathrm{~m}$ (Fig. 8). The sea cucumbers look very impressive with their densely ramified captorial tentacles. Beautiful and variously colored actinians were also plentiful.

Colonies of solitary 6-rayed corals Gerianthus sp. made a fabulous sight. These predominated on muds at depths of 15 to $30 \mathrm{~m}$ (Fig. 9), their population density reaching 540 ind. $\mathrm{m}^{-2}$. They formed a living moving net of interlaced tentacles. Bottom sediments were also populated by several bivalve molluscs, such as a new species, Macoma lukinii, as well as numerous polychaetes, nematodes and some other invertrebrates.

Several species of starfishes, polychaetes, crustaceans and sponges inhabited various depths. It should be noted that many species which are common in Kraternaya Bight do not occur outside the island or on other Kurile Islands.

Soft sediments at different depths were occupied by accumulations of polychaetes building vertical tubes containing numerous commensal crustaceans. At least one new polychaete species of the genus Polydora was found there.

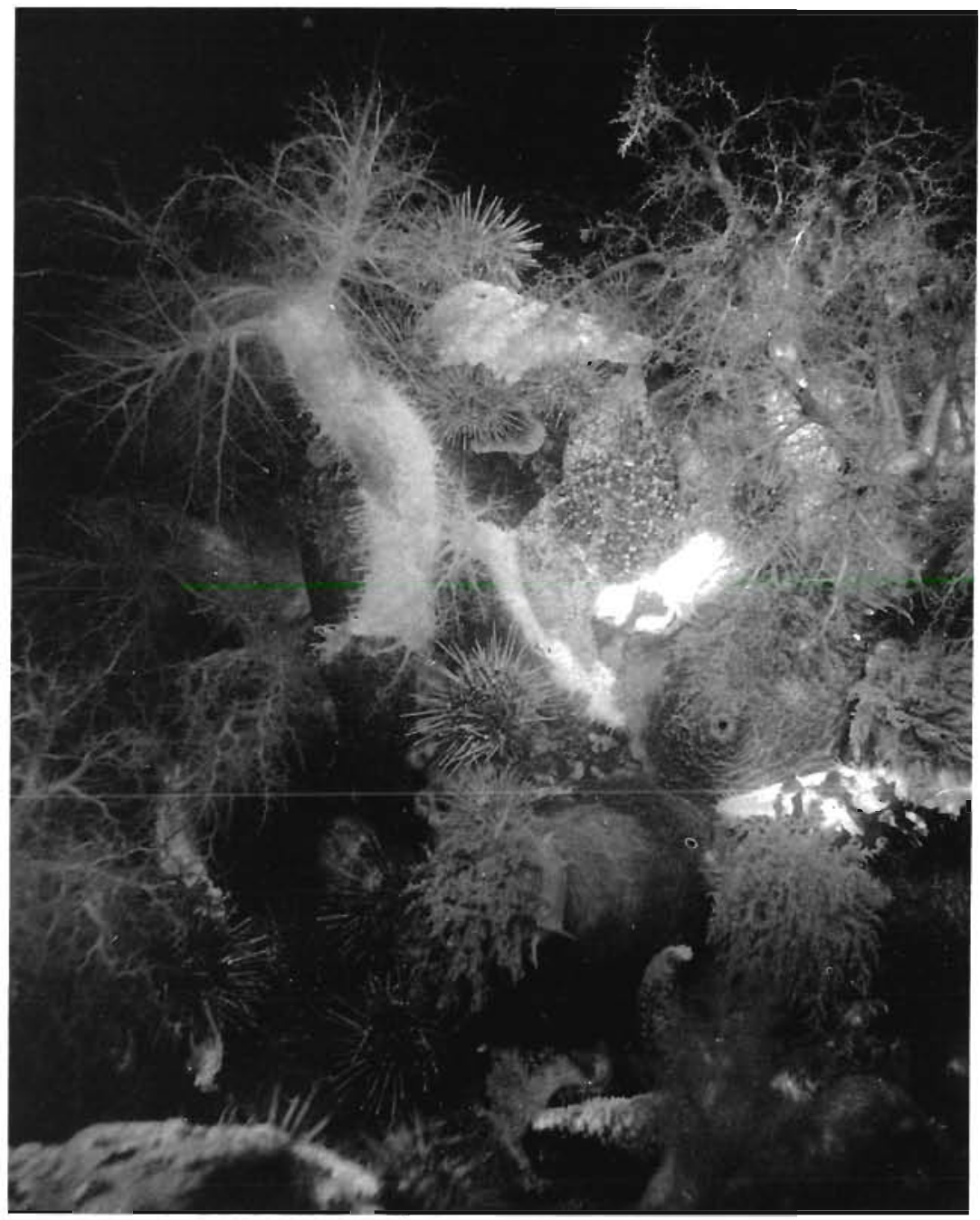

Fig. 7. Holothurians Psolus sp. and Eupentacta pseudoquinquesemita cover rock surface. Depth $15 \mathrm{~m}$ 


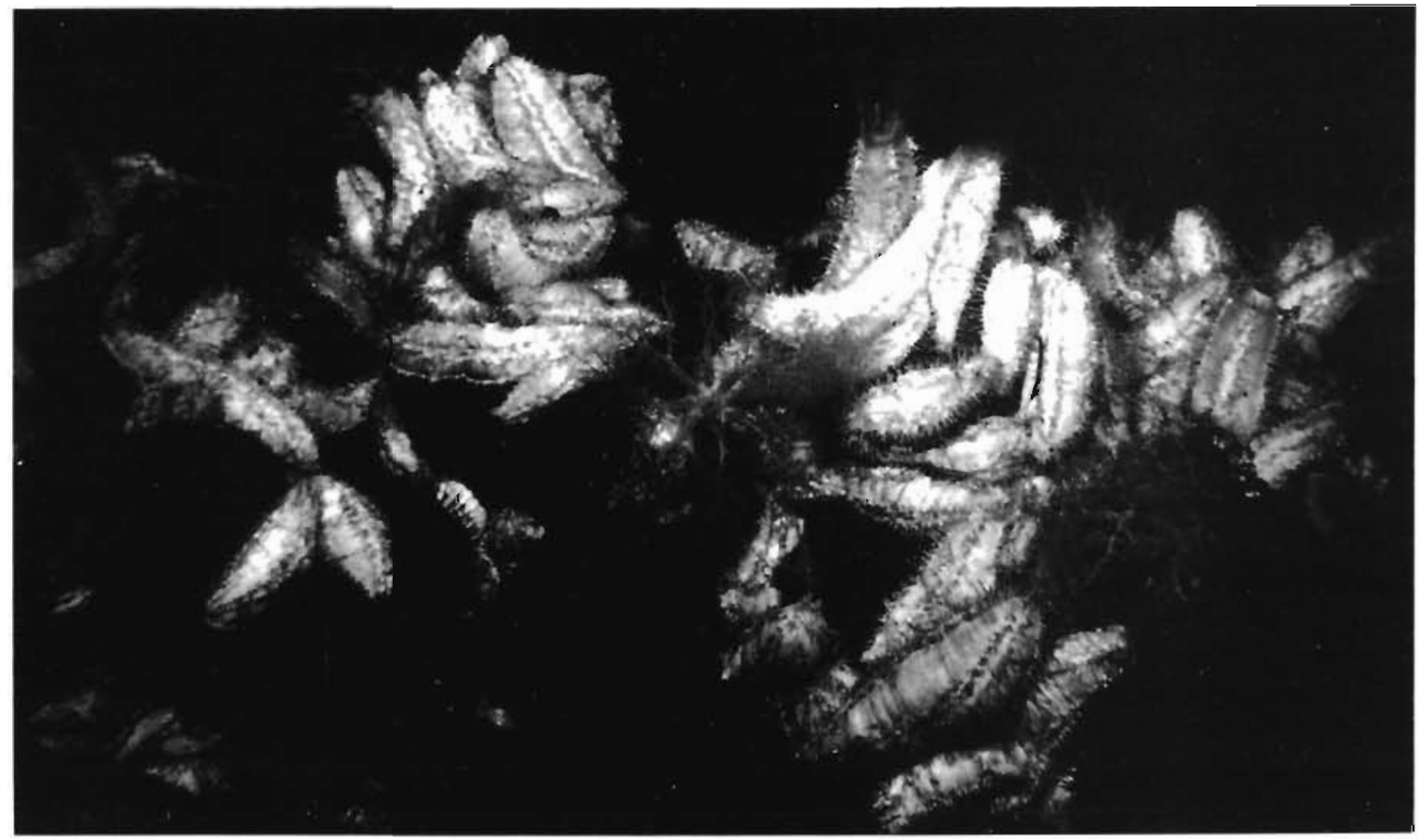

Fig. 8. Community of holothurians Eupentacta pseudoquinquesemita. Depth 10 to $15 \mathrm{~m}$

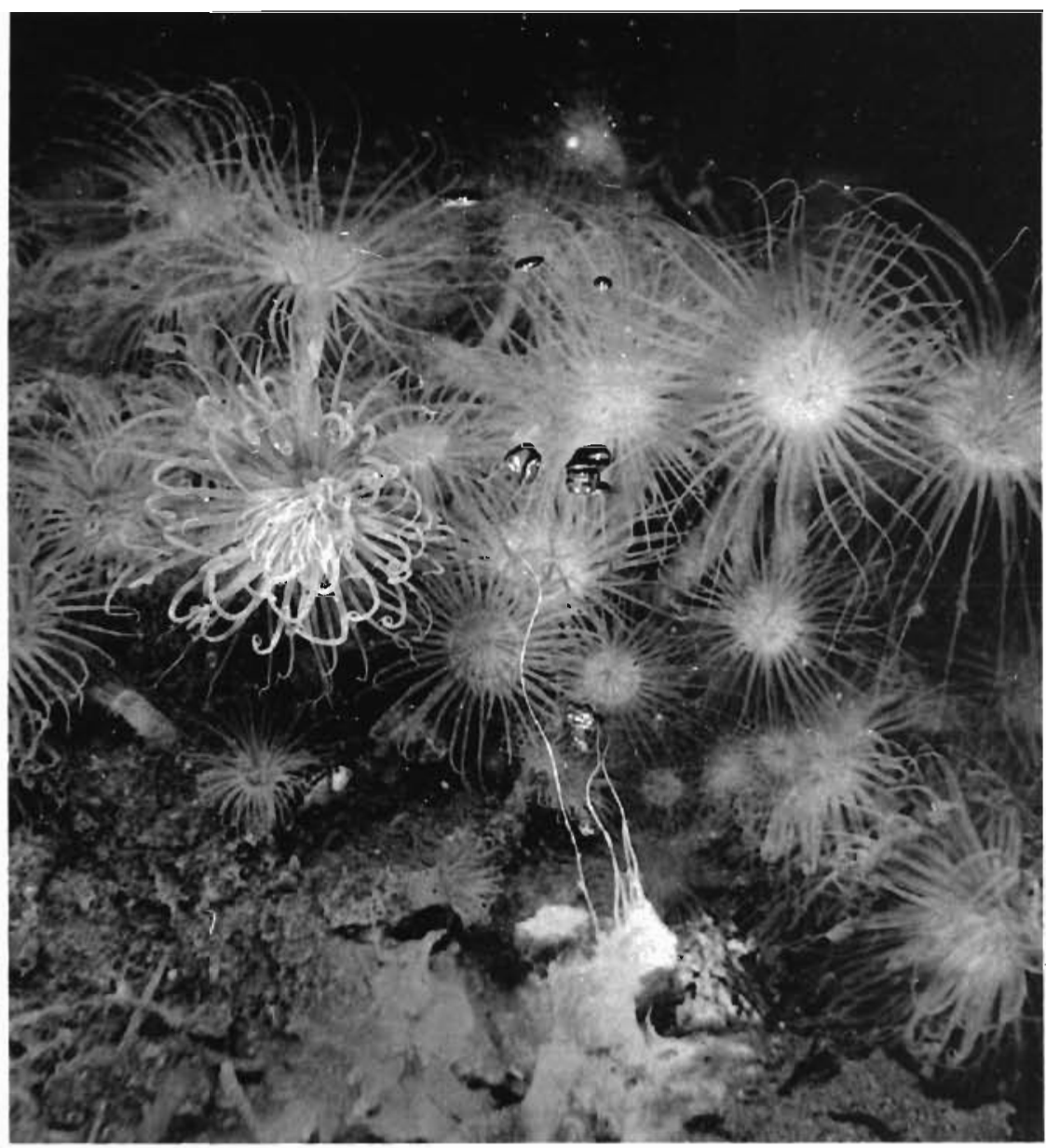

Fig. 9. Solitary six-rayed corals Cerianthus sp. (Anthozoa, Cerianthana) dominate soft sediments and accumulate around gasohydrothermal vents. Bacterial mats develop on the bottom around the vents. Depth $22 \mathrm{~m}$ 
Organisms (some of the dominant species) which have colonized Kraternaya Bight have changed in morphology and adapted to the extreme conditions. They have essentially changed some of their biochemical characteristics: they have a high content of the cytochrom P-450, 5-aminolevulinate synthetase and high rate of the level oxidizing in the microsomal system (Muzyka \& Tarasov 1990).

\section{CONCLUSIONS}

We have studied a unique semiclosed biogeochemical ecosystem; there are gaso-hydrothermal vents and zones seeping volcanic waters and a high abundance and biomass of marine organisms. Probably, homeostasis in the ecosystem is ensured by volcanic activity and high rates of chemo- and photosynthesis which are in balance. Production and transformation of organic matter are mediated by a close interrelation of the carbon, sulphur, iron and manganese cycles. This ecosystem seems to be unique; there is no other reported with similar conditions.

The contents of several elements in some parts of the bight are so high that the bight can be regarded as a model of a highly polluted water body (although it is natural pollution in this case). Thus, we can see how extremely high concentrations of some pollutants affect sea life. However, complete comprehension of the origin and function of the ecosystem in Kraternaya Bight needs participation in the study by specialists in several disciplines. For example, the bottom sediments are over $100 \mathrm{~m}$ thick. Analysis of deep sediment might provide interesting data on the development of life, changes in biogeochemical processes and the formation of an ecosystem. In this regard, it is desirable that expeditions should be made to Kraternaya Bight for 1 to 2 mo every year

We proposed the conservation of this unusual ecosystem in the unique Kraternaya Bight for further studies and for future generations. In 1988, the Executive Committee of the Sakhalin District Soviet agreed to establish a biological reserve in Kraternaya Bight.

\section{LITERATURE CITED}

Borzenkov, I. A., Namsaraev, B. B., Ivanov, M. V (1989). Bacterial formation of methane in the bottom sediments of Kraternaya Bight. Biologiya Morya 3: 65-70 (in Russian)

Corliss, J. B., Dymond, J., Gordon, L. I., Edmond, J. M., Von Herzen, R. P., Ballard, A., Green, K., Williams, D., Baimbridge, A. Crane, K., Van Andel, T H. (1979). Submarine thermal springs on the Galapagos Rift. Science 203: 1073-1083

Gavrilenko, G. M., Bondarenko, V. I., Sazonov, A. P. (1989). Marine volcanological research in Kraternaya Bight (Kurile Islands). Blologiya Morya 3: 19-28 (in Russian)

This review was submitted to the editor
Grassle, J. F., Berg, C. J, Childress, J. J., Grassle, J. P., Hessler, R. R., Jannasch, H. J., Karl, D. M., Lutz, R. A., Mickel, T J., Rhoads, D. C., Sanders, H. L., Smith, K. L., Somero, G. N., Turner, R. D., Tuttle, J. H., Walsh, P. J., Williams, A. J. (1979). Galapagos 79: intitial findings of a deep-sea biological quest. Oceanus 22: 2-10

Karnachuk, O V., Namsaraev, B. B., Ivanov, M. V. (1989). Modera processes of sulphate reduction in the sediment of Kraternaya Bight. Biologiya Morya 3: 59-65 (in Russian)

Khristoforova, N. K. (1989). Dissolved organic matter in Kraternaya Bight waters. Biologiya Morya 3: 44-48 (in Russian)

Kuznetsov, A. P., Rass, T S., Galkin, S. V. (1989). Benthic community of Paramushir gas hydrated source. Zool. J. (Moscow) 68 (I): 5-14

Laubier, L., Desbruyeres, D. (1985). Oases at the bottom of the Ocean. Endeavour 9 (2): 67-76

Lutz, R. A., Hessler, R. R. (1980). Life without sunlight. The Science Teacher 50 (3): $22-29$

Muzyka, V. I., Tarasov, V G. (1991). Effect of gasohydrothermal activity on cytochrom systems of cells of some marine invertebrates of Kurile Islands. In: Tarasov, V. G. (ed.) Shallow-water gasohydrotherms and ecosystems of Kraternaya Bight (Ushishir volcano, Kurile Islands). PVD ANSSSR, Vladivostock (in press) (in Russian)

Namsaraev, B. B., Karnachuk, O. V., Borzenkov, I. A., Starynin, D. A. (1989). Microbiological processes in the bottom sediments of Kraternaya Bight. Biologiya Morya 3: 52-58 (in Russian)

Propp, M. V (1988). Life inside a volcano. Sci. in the USSR 6 : $36-45$

Propp, M. V., Garber, M. R., Ryabushko, V. I. (1982). Unstable processes in the metabolic rate measurements in flowthrough systems. Mar. Biol. 67: 47-49

Propp, M. V., Propp, L. N., Tarasov, V. G. (1989). Hydrochemical conditions and daily dynamics of oxygen, chlorophyll a and biogenj.c elements in Kraternaya Bight. Biologiya Morya 3: 36-44 (in Russian)

Shulkin, V.M. (1989). Geochemistry of metals in the Kraternaya Bight ecosystem. Biologiya Morya 3: 29-36 (in Russian)

Starynin, D. A., Gorlenko, V. M., Ivanov, M. V., Kamachuk, O. V., Namsaraev, B. B. (1989). Algobacterial mats of Kraternaya Bight. Biologiya Morya 3: 70-76 (in Russian)

Strickland, J D. H., Parsons, T A. (1972). A practical handbook of seawater analysis. Bull. Fish. Res. Bd Can 167: $1-310$

Tarasov, V G., Propp, M. V., Propp, L. N., Blinov, S. V., Kamenev, G. M. (1986). Hydrothermal shallow vents and specific ecosystem in Kraternaya caldera (Kurile Islands). Sov. J. mar Biol. 12 (2): 122-125

Tarasov, V G., Propp, M. V., Propp, L. N., Zhirmunsky, A. V. Namsaraev, B. B., Gorlenko, V M., Starynin, D. A. (1990). Shallow-water gaso-hydrothermal vents of Ushishir volcano and the ecosystem of Kraternaya Bight (the Kurile Islands). P.S.Z.N.I. Mar Ecol. 10 (2): 11 (1): 1-23

Turner, R. D. (1981). 'Wood Islands' and thermal vents as centers of diverse communities of the deep-sea. Sov. J. mar Biol. 7 (1): 1--9

Williams, A. B. (1985). Summary comments. In: Jones, M. L. (ed.) Hydrothermal vents of the Eastern Pacific: an overview. Bull. Biol. Soc. Wash. 6: 489-493

Zavarzin, G. A., Vasiljeva, L. V., Trikova, V V (1967). About the participation of microorganisms in the postvolcanic processes. [zvestiya Akademii Nauk SSSR, ser. Bilogicheskaya 4: 3-57 (in Russian) 